\title{
Yeast Mutant Requiring an Organic Solvent for Growth
}

\author{
By F. KARST AND F. LACROUTE \\ Laboratoire de Génétique Physiologique, Institut de Biologie Moléculaire et Cellulaire, \\ Rue René Descartes, 67000 Strasbourg, France
}

(Received 25 March 1974)

\section{SUMMAR Y}

A mutation has been found which makes yeast dependent on either organic solvents or high temperature for growth. This phenotype suggested an impairment in lipid mobility, but a chemical analysis has disproved this hypothesis. A study of the physiology of the mutant shows an impairment in RNA biosynthesis. This may be due either to a primary effect of the mutation or, more probably, to a secondary effect through regulation.

\section{INTRODUCTION}

During a search for sterol-auxotrophic mutants a yeast mutant dependent on organic solvents for growth at low temperature $\left(20^{\circ} \mathrm{C}\right)$, but not at high temperature $\left(34{ }^{\circ} \mathrm{C}\right)$, was accidently found. The most obvious possibility was that an impairment in membrane properties had occurred. Protein-lipid interactions (Singer \& Nicolson, 1972) are important for the biological activity of membrane proteins and can be perturbed by a temperature change (Wilson, Rose \& Fox, 1970) or by an organic solvent (Pauling, 196I). Nevertheless, no significant difference was found at this level. Another possibility was a defect in protein synthesis linked to a cold sensitivity of ribosomal protein assembly (Guthrie, Nashimoto \& Nomura, 1969). Ribonucleic acid and protein synthesis are in fact decreased in the mutant after a shift to low temperature, but this decrease is not apparently a primary effect of the mutation.

\section{METHODS}

Organisms. Saccharomyces cerevisiae, strains flioo (haploid a, wild type) and the isogenic FL200 (haploid $\alpha$, wild type) were used (Lacroute, I971).

Media and culture methods. Yeast nitrogen base (YNB) (Difco) without amino acids, supplemented with I \% glucose, was the ordinary minimal medium. Yeast extract (Difco), $\mathrm{I} \%$, bactopeptone (Difco), I \%, and glucose, $2 \%$, were present in the complete medium.

Mutagenesis and genetic analysis. The wild-type strain, FL100, was treated with nitrous acid to I \% survival and then incubated on solid complete medium containing $4 \%(\mathrm{v} / \mathrm{v}) 95 \%$ ethyl alcohol and $40 \mathrm{mg}$ ergosterol/1. After growth, the cells were replica-plated on complete medium without supplements. Among approximately 240000 colonies tested, one was found which required ethyl alcohol for growth at $28{ }^{\circ} \mathrm{C}$. None required ergosterol for growth. The genetic analyses were performed using the methods of Mortimer \& Hawthorne (1966).

Growth assays. Growth studies were carried out with a Klett-Summerson photoelectric colorimeter (blue filter), in side-arm Erlenmeyer flasks. For qualitative assays of growth ability, a drop of cell suspension was incubated on solid medium and the growth estimated after $48 \mathrm{~h}$ incubation. 
Lipid analysis. Sterols were extracted by saponification with alcoholic $\mathrm{KOH}$, followed by extraction with $n$-hexane. The hexane was vacuum-dried in a stream of nitrogen and the non-saponifiable lipids suspended in chloroform. Ergosterol was determined either by the Liebermann-Burchard reaction, or spectrophotometrically by direct comparison with ergosterol (Shaw \& Jeffries, I963). Total lipids were extracted (Folch, Lees \& SloaneStanley, 1957), and fractionated on silicic acid (Vance \& Sweeley, 1967). Phospholipids were determined as organic phosphorus in the lipid extract (Chen, Toribara \& Warner, 1956).

The phospholipids were separated by thin-layer chromatography on silica gel $G$ plates developed with a mixture of chloroform-methanol-ammonia (140:50:10, v/v) (Neskovic \& Kostic, 1968). The neutral lipids were separated by thin-layer chromatography on silica gel G with a light petroleum-diethyl ether-acetic acid $(80: 20: 1, \mathrm{v} / \mathrm{v})$ as solvent (Longley, Rose \& Knights, 1968).

Fatty acid analysis. Phospholipids were hydrolysed with potassium hydroxide and extracted with chloroform after neutralization by ethyl formate. The chloroform was removed under a stream of nitrogen and the fatty acids were dissolved in an ethyl ether-diazomethane mixture and left overnight. The methyl esters of the fatty acids were separated by gas-liquid chromatography with an Aerograph-Autoprep 705 apparatus (DEGS 15\% column on acid washed chromosorb W).

Determination of soluble amino acids. Cells of an exponentially growing culture were collected by filtration and washed rapidly. The amino acids were extracted for $10 \mathrm{~min}$ with boiling water and separated with a Technicon amino acid analyser.

Determination of the soluble nucleotides pool. After extraction with I \% perchloric acid (PCA), the soluble pool was hydrolysed with potassium hydroxide and the bases separated by paper chromatography (Wyatt, I951).

Measurement of the initial velocity of uptake. Uptake of a given compound was measured by assaying its incorporation as ${ }^{14} \mathrm{C}$-labelled product into the exponentially-growing yeast culture (50 to I00 Klett units). Permease activity was assayed by incubating I $\mathrm{ml}$ samples with the labelled product for $30 \mathrm{~s}$. During this time, uptake was linear with time. The cells were then collected on Millipore membrane filters (pore size $0.45 \mu \mathrm{m} ; 25 \mathrm{~mm}$ diameter) and washed several times with water. The filters were dried and each assayed with $10 \mathrm{ml}$ diphenyl-2,5 orazole-toluol (0.5\%, w/v) in an LS 150 scintillator (Beckman Instruments).

Determination of the cell composition. The yeast cells were collected, washed and resuspended in $9 \mathrm{ml}$ of ice-cold water to which $2 \mathrm{ml}$ of ice-cold $\mathrm{I} \cdot 2 \mathrm{~N}-\mathrm{HCl}$ was then added. The suspension was centrifuged after $20 \mathrm{~min}$, the pellet being resuspended in $0.2 \mathrm{~N}-\mathrm{HClO}_{4}$; after a second centrifugation the supernatant fluid was separated and the pellet suspended in $4 \mathrm{ml}$ water. A portion ( $\mathrm{I} \mathrm{ml}$ ) was assayed for proteins with a biuret reagent. A further portion $(2 \mathrm{ml})$ was hydrolysed in $0.3 \mathrm{~N}-\mathrm{NaOH}$ for $\mathrm{I} \mathrm{h}$ at $37^{\circ} \mathrm{C}$, after which $\mathrm{I} \mathrm{ml}$ of ice-cold $\mathrm{I} \cdot 2 \mathrm{~N}$ $\mathrm{HClO}_{4}$ was added. After centrifugation, the absorbance at $260 \mathrm{~nm}$ of the supernatant solution was measured: the RNA content of the cells was calculated from this value by using an extinction coefficient of $10.5 \mathrm{mmol}^{-1}$ (von Meyenburg, 197I).

Measurement of in vitro protein synthesis. After growth at $34{ }^{\circ} \mathrm{C}$ the yeast strains were suspended in buffer A (50 mm-tris hydroxymethyl aminomethane-chloride $\mathrm{pH}_{7} \cdot 6$, containing $10 \mathrm{~mm}$-magnesium chloride and $50 \mathrm{~mm}$-potassium chloride) and broken for $30 \mathrm{~s}$ in a Braun homogenizer. The homogenate was centrifuged at $25000 \mathrm{~g}$ for $20 \mathrm{~min}$. Ribosomes were collected by centrifugation at $105000 \mathrm{~g}$ for $90 \mathrm{~min}$. In vitro protein synthesis was then assayed (Amesz, 1972). Ribosomes ( $\mathrm{I} \mathrm{mg)} \mathrm{were} \mathrm{incubated} \mathrm{at} 22{ }^{\circ} \mathrm{C}$ in $500 \mu \mathrm{l}$ of a solution containing (per ml): $50 \mu \mathrm{mol}$ tris chloride $\mathrm{pH} 7 \cdot 6,50 \mu \mathrm{mol} \mathrm{KCl,} 8 \mu \mathrm{mol}$ magnesium acetate, $0.3 \mu \mathrm{mol}$ spermidine, $0.15 \mu \mathrm{mol}$ GTP, $0.5 \mu \mathrm{mol}$ ATP, $6.6 \mathrm{nmol}\left[{ }^{14} \mathrm{C}\right]$ leucine (I $50 \mathrm{mCi} / \mathrm{mmol}$ ), 
Table I. Growth characteristics of the osdr-I mutant

\begin{tabular}{|c|c|c|}
\hline Medium & FLIOO & FLIOO osdI-I \\
\hline Complete & +++ & + \\
\hline Minimal & +++ & + \\
\hline Minimal + I M-methanol & $+t$ & ++ \\
\hline Minimal + I m-ethanol & +++ & +++ \\
\hline Minimal+o. I M-propanol & ++ & + \\
\hline Minimal + $0.5 \mathrm{M}$-isopropanol & +++ & +++ \\
\hline Minimal+o. I M-butanol & ++ & ++ \\
\hline Minimal+o. I M-isobutanol & ++ & ++ \\
\hline Minimal +o. I M-amylalcohol & +++ & +++ \\
\hline Minimal $+2 \%(w / v)$ dimethylsulphoxide & ++ & +++ \\
\hline Minimal+o. I M-urea & +++ & 0 \\
\hline Minimal + I M-Glycerol & +++ & + \\
\hline Minimal $+0.5 \mathrm{M}-\mathrm{KCl}$ & +++ & 0 \\
\hline Minimal $+6 \%(w / v)$ ethylene glycol & +++ & + \\
\hline Minimal +o.o $\mathrm{M}-\mathrm{MgCl}_{2}$ & +++ & 0 \\
\hline Minimal +0.025 M-triethanolamin & ++ & ++ \\
\hline
\end{tabular}

The growth on solid medium was estimated after $48 \mathrm{~h}$ incubation at $22{ }^{\circ} \mathrm{C}$. The compounds were added at the optimal concentration for the growth of the $o s d-I-I$ mutant when they relieved it. The growth scale is as follows;,,,,+++++++++ 0 .

$6.6 \mathrm{nmol}\left[{ }^{14} \mathrm{C}\right]$ lysine $(\mathrm{I} 20 \mathrm{mCi} / \mathrm{mmol}), 60 \mathrm{nmol}$ of the other $\mathrm{I} 8$ common amino acids, $500 \mu \mathrm{g}$ tRNA from yeast, and I $\mathrm{mg}$ of the supernatant protein. Hot trichloracetic acid precipitable radioactivity was measured as described above.

Chemicals. Biochemicals were purchased from Calbiochem, Sigma, and E. Merck A.G., Darmstadt, Germany. Labelled products were purchased from the C.E.A., Saclay, France.

\section{RESULTS}

\section{Growth characteristics}

The mutation obtained as indicated in Methods was named osdI-I (organic solvent dependent). The $o s d I-I$ mutant strain failed to form colonies in the temperature range 20 to $30^{\circ} \mathrm{C}$, on complete or minimal medium. At $34^{\circ} \mathrm{C}$ the growth of the mutant was similar to that of the wild-type FLIOo. At $20^{\circ} \mathrm{C}$ the growth of the mutant could be obtained if certain solvents were added (Table $\mathrm{I}$ ). Neither addition of monovalent or divalent cations, nor raising the osmotic pressure of the medium, helped the growth of the mutant.

In liquid minimal medium the doubling time of the mutant was $18 \mathrm{~h}$ I $5 \mathrm{~min}$ instead of $6 \mathrm{~h} 40 \mathrm{~min}$ for the wild-type strain (Fig. I). At a permissive temperature $\left(34^{\circ} \mathrm{C}\right.$ ) the respective doubling times were $3 \mathrm{~h} 30 \mathrm{~min}$ and $2 \mathrm{~h} 45 \mathrm{~min}$.

At the non-permissive temperature the growth of the mutant was best in the presence of $0.6 \mathrm{M}$-ethyl alcohol (doubling time $5 \mathrm{~h} \mathrm{I} 5 \mathrm{~min}$ at $23^{\circ} \mathrm{C}$ ) (Fig. 2); under the same conditions the doubling time of the wild type was $5 \mathrm{~h}$. At a $0.8 \mathrm{M}$ concentration of ethyl alcohol both the mutant and the wild-type strains showed the same doubling time: $5 \mathrm{~h} 30 \mathrm{~min}$. at $23^{\circ} \mathrm{C}$.

After a temperature shift from 34 to $20^{\circ} \mathrm{C}$ the exponential growth of the mutant resumed but with a lower rate (Fig. 3). The initial growth rate was higher than usual at $20^{\circ} \mathrm{C}$ and it only slowly fell to its definitive value. Conversely, when the shift was done from 22 to $34^{\circ} \mathrm{C}$, the osd mutant only slowly reached its final growth rate determined at $34{ }^{\circ} \mathrm{C}$. 


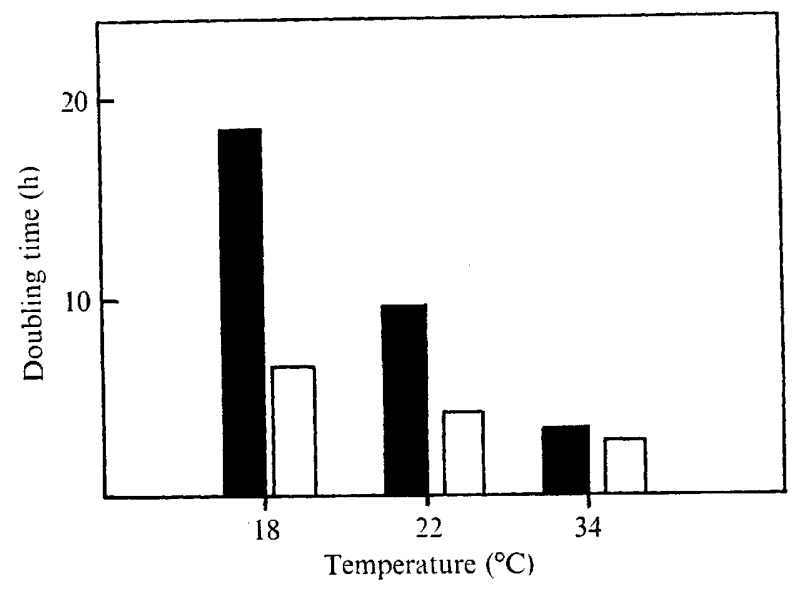

Fig. I. Effect of the temperature on the doubling time of the wild-type FLIOO ( $\square$ ) and the $o s d I-I$ mutant $(\mathbf{\square})$. The growth rate was determined after overnight growth in YNB.

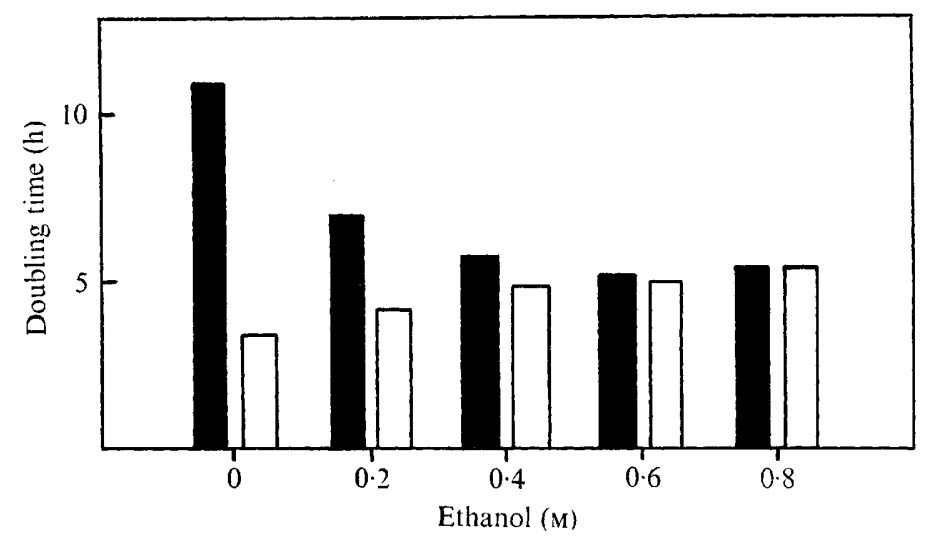

Fig. 2. Effect of ethanol on the doubling time of the strains FLIO0 ( $\square$ ) and FLIO0 osdr-r (四). The yeasts were grown in YNB at a temperature of $23{ }^{\circ} \mathrm{C}$.

\section{Genetic analysis of the osdI-I mutant}

The osdI mutation was recessive, could be suppressed, and exhibited a $2: 2$ nuclear inheritance. All I I spontaneous revertants tested were suppressed and not back-reverted. We tried to determine how many suppressor loci were involved. The cross between an ( $o s d I-I$ sup) strain and the (osdI-I, sup $\left.{ }^{-}\right)$strain showed that the suppressor was semidominant since the diploids $o s d I-I$, $\sup ^{+} \mid o s d I-I$, sup ${ }^{-}$were wild type. It was therefore not possible to determine the number of suppressor loci for the $o s d I-I$ mutation by using the phenotypic complementation analysis.

To investigate whether the $o s d I-I$ mutation was a missense or a nonsense mutation, we crossed the $0 s d I-I$ strain with strain 2260-5B (Hawthorne, 1969), which carries several auxotrophic ochre and amber nonsense mutations, and we isolated the recombinant strain: (osdI-I leu ile ade phe tyr try). Revertants either for one auxotrophy or for the $o s d I-I$ mutation were analysed. Among 15 revertants of the first type which we analysed, none was reverted for the Osd phenotype. Similarly no auxotrophic revertants were found among the i 3 spontaneous or the I I u.v.-induced $o s d I$-I revertants. Furthermore, no simultaneous double 


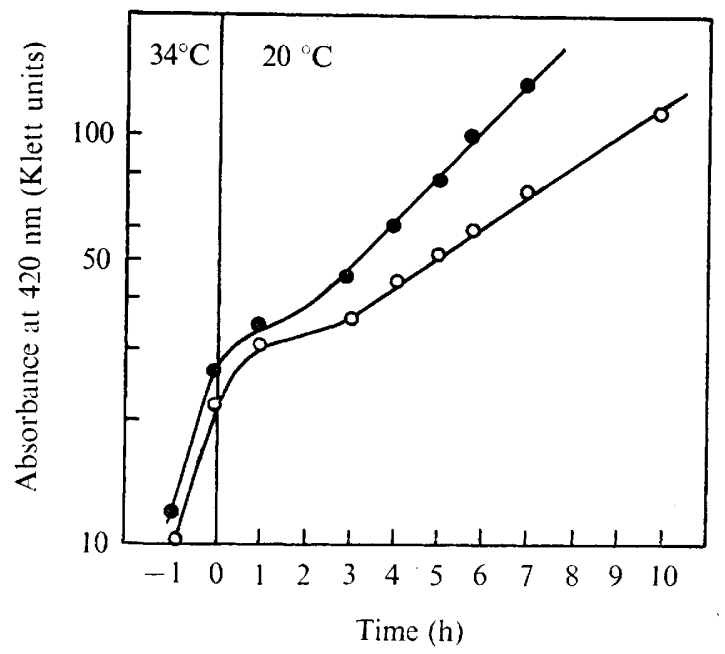

Fig. 3. Response of wild type and $o s d I-I$ mutant upon temperature shift from 34 to $20^{\circ} \mathrm{C}$ in minimal medium. The absorbance of exponentially growing cultures of wild type (O) and FLIOo $o s d I-I(O)$ was followed at $420 \mathrm{~nm}$. At time $o$ the cultures were shifted to the new temperature by immersion in a water bath.

Table 2. Fatty-acid composition of the phospholipids in the wild type and osd mutant

$\begin{array}{ccc}\text { Fatty acid } & \text { FLIOO }(\%)^{*} & \text { FLIOO osdI-I }(\%)^{*} \\ \text { I2:0 } & 0.07 & 0.06 \\ \text { I4:0 } & 0.77 & 0.87 \\ \text { I6:0 } & 17.11 & 15.24 \\ \text { I6: I } & 52.16 & 53.58 \\ \text { I8:0 } & 2.02 & 1 \cdot 52 \\ \text { I 8: } & 27.77 & 28.73\end{array}$

The strains FLIOO and FLIOO osd were collected after growth at $34{ }^{\circ} \mathrm{C}$ and the fatty-acid constituents of the phospholipids prepared as described in Methods.

* The number of moles of each component was expressed as a percentage of the corresponding sum of all the components.

reversion was obtained when a lawn of the isolated complex strain was plated on a medium providing the selection of revertants of one type of auxotrophy and incubated at $18{ }^{\circ} \mathrm{C}$. It therefore seemed probable that the osdI-I mutation was a missense mutation, suppressible either at a metabolic level or by mutation in tRNA.

\section{Biochemical basis of the mutation}

Lipid analysis. The fact that the mutant strain FLI oo $o s d I-I$ could grow either with organic solvents or at a high temperature could have been due to a modified lipid composition in the cytoplasmic membrane. This modification could increase the membrane rigidity, which could again be reduced either through addition of an organic solvent or through an elevation of the growth temperature. A comparative lipid analysis was therefore carried out on the mutant and the wild-type strains grown at $34^{\circ} \mathrm{C}$. The amount of ergosterol, as described in Methods, was the same in both strains: $2 \mathrm{I} \cdot 0 \mu \mathrm{g}$ ergosterol $/ \mathrm{mg}$ protein in the wild type, and $22.6 \mu \mathrm{g}$ in the mutant strain. 

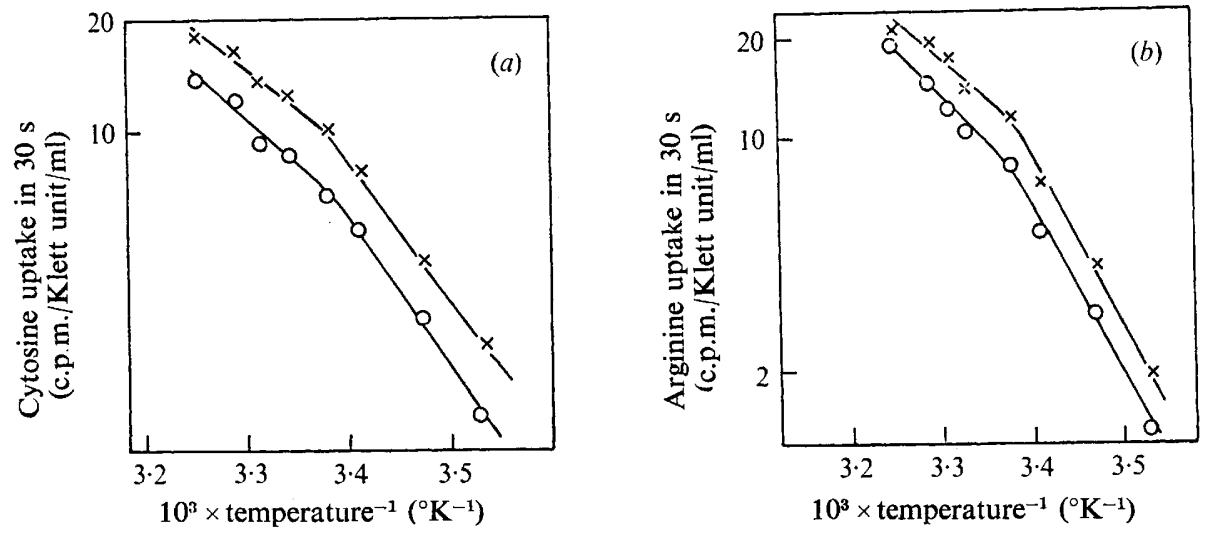

Fig. 4. Arrhenius representation of initial velocity of $(a)$ cytosine and $(b)$ arginine uptake. The strains FLIOO $(x)$ and FLIOO osdI-I $(O)$ being in exponential growth, I ml of the growth medium was sampled into a test-tube kept in a water bath at the desired temperature for $5 \mathrm{~min}$. A $0.1 \mathrm{ml}$ sample of radioactive solution of $\left[{ }^{14} \mathrm{C}\right]$ cytosine $(13 \mu \mathrm{g} / \mathrm{ml}, 0.1 \mu \mathrm{Ci} / \mathrm{ml})$ or $\left.{ }^{14} \mathrm{C}\right]$ arginine $(50 \mu \mathrm{g} / \mathrm{ml}$, $0.5 \mu \mathrm{Ci} / \mathrm{ml})$ was added. After $30 \mathrm{~s}$ the mixture was filtered through a membrane filter $(0.6 \mu \mathrm{m}$ pore size) and washed with $2 \times 10 \mathrm{ml}$ ice-cold distilled water.

Table 3. Composition of amino acid pool

\begin{tabular}{|c|c|c|c|c|c|}
\hline \multirow[b]{3}{*}{ Amino acid } & \multicolumn{3}{|c|}{ Wild-type FLIOO, at $\left({ }^{\circ} \mathrm{C}\right)$ : } & \multirow{2}{*}{\multicolumn{2}{|c|}{ FLIOo osd $I-I$, at $\left({ }^{\circ} \mathrm{C}\right)$}} \\
\hline & 34 (with & & & & \\
\hline & cycloheximide) & 34 & $2 \mathrm{I}$ & 34 & $2 \mathrm{I}$ \\
\hline Aspartic acid & I 3.0 & $9 \cdot 4$ & $10 \cdot 0$ & 14.0 & $13 \cdot 4$ \\
\hline Threonine & $10 \cdot 0$ & 5.9 & $28 \cdot I$ & $22 \cdot 8$ & $3 I \cdot 6$ \\
\hline Serine & I3.4 & $7 \cdot 9$ & $5 \cdot 2$ & $7 \cdot 7$ & - \\
\hline Glutamic acid & $72 \cdot 0$ & $49 \cdot 7$ & $45^{\circ} 9$ & $73 \cdot I$ & $65 \cdot 8$ \\
\hline Glycine & $7 \cdot 6$ & $2 \cdot 6$ & $2 \cdot 7$ & 10.7 & $7 \cdot 1$ \\
\hline Alanine & $27 \cdot 6$ & 10.0 & $11 \cdot 5$ & $28 \cdot I$ & I5. I \\
\hline Valine & $3 \cdot 8$ & $I \cdot 4$ & $I \cdot 5$ & $3 \cdot 6$ & $4 \cdot 9$ \\
\hline Lysine & $30 \cdot 9$ & $6 \cdot 2$ & $4 \cdot 4$ & $27 \cdot 8$ & $28 \cdot 3$ \\
\hline Histidine & $11 \cdot 2$ & $2 \cdot 3$ & $2 \cdot 9$ & $8 \cdot 3$ & $12 \cdot 0$ \\
\hline Arginine & $82 \cdot 4$ & $34 * 3$ & $29 \cdot 5$ & I $12 \cdot 4$ & I09.5 \\
\hline
\end{tabular}

The results are expressed in $\mu \mathrm{mol} / \mathrm{g}$ dry wt yeast. Both strains were grown in minimal medium at $34^{\circ} \mathrm{C}$, and a portion shifted to $21{ }^{\circ} \mathrm{C}$ for $8 \mathrm{~h}$. The wild type was also grown at $34^{\circ} \mathrm{C}$ in the presence of $50 \mu \mathrm{g}$ cycloheximide/ml. The amino acid pool was assayed as described in Methods.

The same phospholipids were present, in similar amounts, in both strains: $2 \cdot 5 \mu \mathrm{g}$ organic $\mathrm{P} /$ $\mathrm{mg}$ protein for the wild type, and $2.4 \mu \mathrm{g} / \mathrm{mg}$ protein for the mutant. The contents of neutral lipids, were also similar, as were the fatty acids (Table 2). Hence the cold sensitivity of the $o s d r-I$ mutant was not due to a change in the fatty-acid composition. Even with an identical chemical composition of the lipids in both strains, a modification in the proteinlipid interactions at the membrane level could still be obtained, however, by the mutation of a membrane protein.

Study of initial velocity of uptake as a function of temperature. The uptake of two compounds was measured: arginine and cytosine. Fig. 4 shows that both permease activities were of the same order in both the mutant and the wild-type strains. Furthermore the transition temperature in the Arrhenius plot was identical and took place between 19 and $21{ }^{\circ} \mathrm{C}$. The small decrease of $35 \%$ found in the mutant may have been the result of its larger pool of amino acids and nucleotides. 
Table 4. Uracil and adenine pools

\begin{tabular}{|c|c|c|c|c|}
\hline \multirow[b]{2}{*}{ Base } & \multicolumn{2}{|c|}{ Wild-type FLIOO } & \multicolumn{2}{|c|}{ FL100 osd } \\
\hline & $34^{\circ} \mathrm{C}$ & $2 \mathrm{I}{ }^{\circ} \mathrm{C}$ & $34^{\circ} \mathrm{C}$ & $21{ }^{\circ} \mathrm{C}$ \\
\hline Uracil & $\mathrm{I} \cdot 5$ & $1 \cdot 6$ & $I \cdot 2$ & $2 \cdot 8$ \\
\hline Adenine & $2 \cdot 0$ & $1 \cdot 7$ & $2 \cdot 4$ & $4 \cdot 9$ \\
\hline
\end{tabular}

The results are expressed in $\mu \mathrm{mol} / \mathrm{g}$ dry wt yeast. The wild-type and the mutant strains were grown in minimal medium at 34 and $2 \mathrm{I}{ }^{\circ} \mathrm{C}$, and their uracil and adenine contents determined as described in Methods.

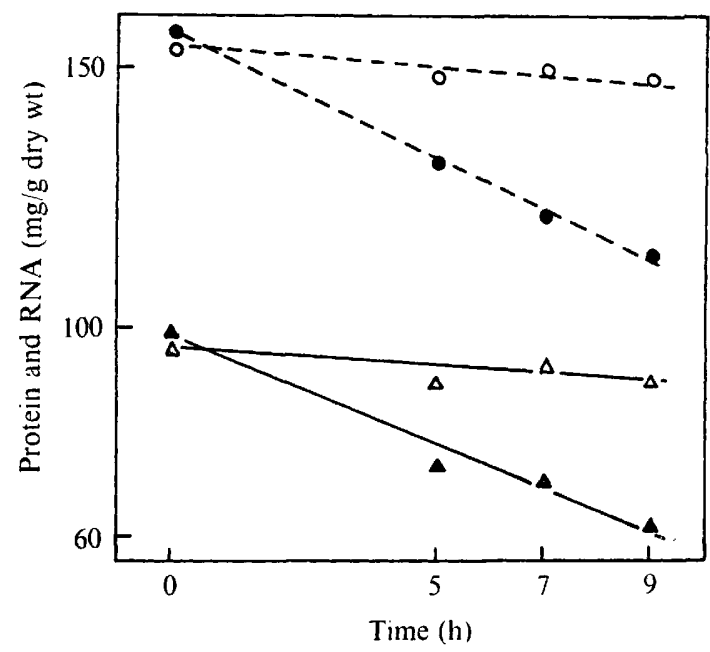

Fig. 5. RNA (-_) and protein (_. - ) content of the strains FL IOO (open symbols) and FL100 osdI $-I$ (solid symbols), after growth at $34^{\circ} \mathrm{C}$ and shift to $2 \mathrm{I}{ }^{\circ} \mathrm{C}$. After overnight growth in minimal medium at $34^{\circ} \mathrm{C}$, the cultures were shifted at time $o$ to the new temperature.

Free amino-acid pool determination. The wild-type and $o s d I-I$ strains were grown at both 34 and $2 \mathrm{I}{ }^{\circ} \mathrm{C}$ for four generations and the cells collected by filtration. The free amino acids were extracted with hot water and assayed. Table 3 shows that the $o s d I-I$ strain contained larger amounts of all the amino acids. A similar increase occurred in the wild type in the presence of cycloheximide and this suggested that the accumulation in $o s d I-I$ may have been a consequence of protein biosynthesis being impaired.

Uracil and adenine pool analysis. The wild-type and $o s d I-I$ strains were grown at 34 and 2 I ${ }^{\circ} \mathrm{C}$. The pool of soluble bases and nucleotides was extracted, and the amounts of uracil and adenine determined (Table 4). The results show that the $o s d I-I$ mutant had a uracil and adenine pool which was twice as large at $2 \mathrm{I}{ }^{\circ} \mathrm{C}$ as at $34{ }^{\circ} \mathrm{C}$. At $34{ }^{\circ} \mathrm{C}$ the pool was similar to that of the wild type. This suggests that RNA biosynthesis in the mutant was impaired at the lower temperature.

$R N A$ and protein biosynthesis. The incorporation of $\mathrm{L}-\left[{ }^{14} \mathrm{C}\right]$ leucine and $\left[{ }^{14} \mathrm{C}\right]$ adenine in the wild and $o s d I-I$ mutant after a shift from 34 to $I 8^{\circ} \mathrm{C}$ was measured. The increases in protein per extinction unit were the same in both strains, but there was a $50 \%$ decrease in the RNA increment per extinction unit in the mutant compared with the wild type. However, the pool of adenylic compounds was higher in the mutant than in the wild type and this must have decreased the specific radioactivity of adenine in the pool. Because of these uncertain- 
Table 5. In vitro protein synthesis in cell-free system of the wild-type and the osdI-I mutant grown at $34{ }^{\circ} \mathrm{C}$

\begin{tabular}{|c|c|c|c|}
\hline & Zero time & $\begin{array}{c}20 \mathrm{~min} \\
\text { incubation }\end{array}$ & $\begin{aligned} & 20 \min \\
+ & \mathrm{DMSO} 2 \%\end{aligned}$ \\
\hline $\begin{array}{l}\text { Wild-type supernatant } \\
\text { Wild-type ribosomes }\end{array}$ & 32 & 339 & 385 \\
\hline $\begin{array}{l}o s d I-I \text { supernatant } \\
o s d I-I \text { ribosomes }\end{array}$ & 13 & $45 \mathrm{I}$ & 532 \\
\hline $\begin{array}{l}\text { Wild-type supernatant } \\
\text { osdI-I ribosomes }\end{array}$ & 32 & 462 & 479 \\
\hline $\begin{array}{l}\text { osdI-I supernatant } \\
\text { Wild-type ribosomes }\end{array}$ & 22 & 356 & 409 \\
\hline
\end{tabular}

Incorporation of $\left[{ }^{14} \mathrm{Clarginine}\right.$ and $\left[{ }^{14} \mathrm{C}\right]$ leucine into the in vitro protein synthesizing system.

The given numbers are the counts per minute and the calculations show that the incorporation obtained corresponds about to 0.7 mole amino acid per ribosome.

ties, other experiments were undertaken using uracil-leucine auxotrophic strains carrying either wild-type or mutant alleles for the $o s d I-I$ gene. These two strains were grown at $34{ }^{\circ} \mathrm{C}$ in the presence of $\mathrm{L}-\left[{ }^{14} \mathrm{C}\right]$ leucine or $\left[{ }^{14} \mathrm{C}\right]$ uracil for six generations and then shifted to $22{ }^{\circ} \mathrm{C}$. The increase in radioactivity in the interval from 6 to $8 \mathrm{~h}$ after the shift was divided by the increase in extinction during the same period. There was again no appreciable difference in the protein increments but the increase in RNA was about $50 \%$ less in the mutant than in the wild type.

As the sensitivity of these measurements was low, the protein and RNA content/cell dry wt after a shift from 34 to $2{ }^{\circ} \mathrm{C}$ was determined by direct chemical estimation. Fig. 5 gives the mean of two experiments and shows that both RNA and protein content decreased in the mutant after the shift. The discrepancy between this experiment and the incorporation of radioactive precursors is not understood.

An analysis of protein synthesis in vitro has been done with the mutant and the wild type grown overnight at $34{ }^{\circ} \mathrm{C}$ (Table 5). No significant difference was found between the two strains. However, the uptake corresponded to only $0.7 \mathrm{~mol}$ amino acid/ribosome, and, in the mutant, some step in protein biosynthesis might be impaired that was not involved in this assay.

\section{DISCUSSION}

While the membrane properties of strain $o s d I-I$ closely resemble those of the wild type, we have not excluded the possibility of defects in a protein of the nuclear membrane, or of the endoplasmic reticulum, as opposed to the cytoplasmic membrane.

This mutation thus appears to affect a different function from that affected by the mutation in Escherichia coli described by Fried \& Novick (1973), which is partly corrected by ethanol. Their mutant is resistant to ethanol and has an altered lactose permeation (not in gene $\mathrm{Y}$ itself) which led the authors to think that the cytoplasmic membrane was defective.

The accumulation of free amino acid in the $\operatorname{ssd} I-I$ mutant, as well as the increase of the uracil and adenine pool at low temperatures and the reduction of the amounts of ribonucleic acids and proteins after a shift to low temperature, seem to show that macromolecular synthesis was impaired. This could be either an indirect secondary effect of the mutation or an indication that a part of the RNA-synthesizing machinery was affected. We have no evidence to discriminate between these possibilities.

Cold-sensitive mutants for which the molecular basis of the mutation has been discovered 
are of two types: an enzyme may become hypersensitive to feed-back inhibition so that the synthesis of an essential compound is prevented at the low temperature (O'Donovan \& Ingraham, 1965); or mutants altered in ribosomal proteins (Guthrie et al. 1969) may lead to abnormal ribosomal assembly.

As there was a long delay, not only for the growth inhibition when shifting from high to low temperature but also for growth recovery when shifting from low to high temperature for our mutant, the first explanation seems unlikely. If one thinks of the effect of ethanol on miscoding in vitro (So \& Davies, I 964) and in vivo (Gorini, Rosset \& Zimmerman, 1967), one might consider that we were dealing with a change in a ribosomal protein causing misreading at low temperature which could be corrected by organic solvents; the lowering of RNA synthesis would then be a secondary effect of this ribosomal mutation.

The determination of the molecular basis of the behaviour of this mutant will be difficult since it displays pleiotropic defects. Nevertheless the relieving effect of such different agents as temperature, alcohols, or dimethylsulphoxide suggests that a change in the secondary or tertiary structure of a macromolecule has occurred.

We thank Dr D. Peter for the analysis of amino acid pools and Dr G. Rebel for helpful and stimulating discussions and for the fatty acid chromatographic analysis. This work has been supported by grants from the Délégation Générale à la Recherche Scientifique et Technique (no. 717.3034I) and from the Institut National de la Santé et de la Recherche Médicale (no. 7I . I.0472), and by a gift from the Fondation pour la Recherche Médicale.

\section{REFERENCES}

Amesz, W. J. C. (1972). Studies on yeast polysomes, ribosomes and subunits. Thesis, University of Utrecht, the Netherlands.

Chen, P. S., Toribara, T. Y.\& WARner, H. ( I956). Microdetermination of phosphorus. Analytical Chemistry 28, $1756-1763$.

Folch, J., Lees, M. \& Sloane-Stanley, G. H. (I957). A simple method for the isolation and purification of total lipids from animal tissues. Journal of Biological Chemistry 266, 497-509.

Fried, V. A. \& Novick, A. (1973). Organic solvents as probes for the structure and function of the bacterial membrane: effects of ethanol on the wild type and an ethanol-resistant mutant of Escherichia coli K 12. Journal of Bacteriology 114, 239-248.

Gorini, L., Rosset, R. \& Zimmerman, R. A. (1967). Phenotypic masking and streptomycin dependence. Science, New York 157, 1314-1317.

Guthrie, C., Nashimoto, H. \& Nomura, N. ( I969). Cold sensitive mutants defective in ribosome assembly. Proceedings of the National Academy of Sciences of the United States of America 63, 384-39I.

HAWTHORNE, D. C. (1969). Identification of nonsense codons in yeast. Journal of Molecular Biology 43, 7I75.

LACROUTE, F. (197I). Non-Mendelian mutation allowing ureidosuccinic acid uptake in yeast. Journal of Bacteriology 106, 519-522.

Longley, R. P., Rose, A. H. \& Knights, B. A. (I968). Composition of the protoplast membrane from Saccharomyces cerevisiae. Biochemical Journal 108, 40I-4I 2.

vON MeyenburG, K. (197I). Transport limited growth rates in a mutant of E. coli. Journal of Bacteriology ro7, 878-887.

Mortimer, R. K. \& Hawthorne, D. C. (1966). Genetic mapping in Saccharomyces cerevisiae. Genetics 58, I65-173.

Neskovic, N. M. \& Kostic, D. M. (1968). Quantitative analysis of rat liver phospholipids by a thin layer chromatographic procedure. Journal of Chromatography 35, 297-300.

O'Donovan, G. A. \& Ingraham, J. L. (1965). Cold sensitive mutants of Escherichia coli. Proceedings of the National Academy of Sciences of the United States of America 54, 451-457.

Pauling, L. (196r). A molecular theory of general anesthesia. Science, New York 134, I5-21. 
ShAW, W. H. C. \& JefrRies, J. P. (1963). The determination of ergosterol in yeast. I. The ultra-violet absorption of purified ergosterol. Analyst 78, 509 514.

Singer, S. J. \& Nicolson, G. L. (1972). The fluid mosaic model of the structure of cell membranes. Science, New York 175, 720 730.

So, A. \& DAvies, E. W. (1964). The effect of organic solvents on protein synthesis and their influence on the amino-acid code. Biochemistry 3, I165-II69.

VANCE, D. E. \& SweEley, C. C. (1967). Quantitative determination of the neutral glycosyl ceramides in human blood. Journal of Lipid Research 8, 62 I-630.

WiLson, G., Rose, S. P. \& Fox, C. F. (1970). The effect of membrane lipid unsaturation of glycoside transport. Biochemical and Biophysical Research Communications 33, 617-623.

WyATT, G. R. (195I). The purine and pyrimidine composition of deoxypentose nucleic acids. Biochemical Journal 48, 584-590. 